Article

\title{
Folk Elements in Aleksei Balabanov's Brat and Brat 2: A Morphological Analysis
}




\section{ABSTRACT}

The article uses Vladimir Propp's Morphology of the Folktale (Морфология сказки, 1928) as a framework to illustrate the way in which Aleksei Balabanov masterfully creates a modern folk tale using classic motifs and structures in his 1997 film Brother (Epam, Russia) and its sequel Brother 2 (Epam 2, Russia, 2000). The paper argues that Brother and Brother 2 are post-Soviet retellings of classic tales of Russian folklore and that Danila is a modern hero, an unlikely saviour of the Russian nation and the Russian soul. Danila's journey is formulaic, predictable and straightforward, yet nevertheless makes for a powerfully new take on concepts of Russian nationalism and heroism. The underworld to which our hero must journey is located in the heart of Russia's 'Peter', and possession of the Russian nation and soul are the object of his quest in the volatile post-Soviet period.

Folk and fairy tales illuminate the way. They anticipate the millennium. They ferret out deep-rooted wishes, needs, and wants and demonstrate how they all can be realized. In this regard, folk and fairy tales present a challenge, so within the tales lies the hope of selftransformation and a better world. (Zipes 1979: xi)

The premier of Aleksei Balabanov's Brother (Epam, Russia, 1997) came at a time when Russia was in search of a new 'self' and, quite literally, a new national idea. In the Kremlin, President Boris Yeltsin pushed his aides to develop this national idea in order to provide a framework for policy and social consciousness in the seemingly free-forall environment that marked his tenure. In 1996, Российская газета even sponsored a contest for the best 'national idea' and promised a ten-million rouble prize to the victor (Obojski 1996). While Balabanov may not have created his epic in response to any politicised appeal, the success of his films can at least, in part, be explained by the national craving for a post-Soviet hero. In the midst of a yet another time of troubles, the Russian population was primed to embrace a tale that offered them not only an escap- ist adventure, but seemed to reflect so well their own anxieties about the new realities of post-Soviet life. It is not surprising that the film's protagonist, Danila, so quickly became a cult hero, an emblem of Russian nationalism and an embodiment of the 'new Russia' (Birchenough 2000: 20; Larsen 2003: 508-511). Indeed, Danila emerges from Aleksei Balabanov's two blockbuster films Brother and its sequel Brother 2 (Бpam 2, Russia, 2000) as the uncontested hero of the post-Soviet period.

\footnotetext{
Balabanov's two films chronicle the adventure-journey of Danila Bagrov (Sergei Bodrov, Jr.). The naive and mysterious Danila ventures to St. Petersburg to seek out his older brother, journeys to the underworld of the city's mafia and eliminates those who do evil to Russians. In the sequel, he continues his journey in Moscow and America where he asserts Russian authority and moral superiority, returning home to the Motherland a heroic defender of the country's ideals and values.
} 
In this article, I will argue that one reason for the success of Brat and Brat 2, and Danila's status as a cult hero, is Balabanov's complex and systematic use of folk narratives and structure. The folkloric framework of the films not only makes the story familiar, but contributes greatly to the viewers' ability to identify on a deeply personal level with Danila. I will argue that Balabanov not only includes elements of Russia's folkloric traditions, as observed by Susan Larsen, ${ }^{2}$ but that his two films actually follow the distinctive structure outlined by Vladimir Propp in his landmark exploration of the Russian wonder tale, Morphology of the Folktale (Морфология сказки, 1928) (Propp 1968). I will argue that the very structure of the films' narratives brings the folk to the forefront, allowing viewers to contextualise Danila's quest in the broader spectrum of Russian heroism and history. In addition to offering a structural analysis of the film based on Propp's morphology of the folktale, I will look at the ways in which the use of the folktale formula in the 1990s fits an important historical pattern of Russian cultural productions, particularly during times of confrontation with the West and the advent of new social and political realities. I will also examine the ways Balabanov infuses his hero with the historicism, patriotism and epic qualities of the heroes found in another category of Russian tales, the bylina (былина, еріс). This blending of genres allows Balabanov to create a character that resonates on multiple levels with an audience deeply connected to its literary and folkloric past.

Larsen discusses the importance of the 'folk' in her seminal 2003 article, noting that 'Balabanov created a fairy tale for post-Soviet audiences' (2003: 508). However, an in-depth assessment of the folk structure of the film is not the main focus of her article which instead highlights the importance of Brat in defining post-Soviet masculine identity. In her dissertation, Ira Österberg offers an analysis of Brat, incorporating Propp's morphology. She condenses all 31 functions into the first film, finding just 27 (Österberg 2006: 10) and does not extend her analysis to Brat 2. She and I differ in our interpretations of the roles of Hoffmann, the assigning of morphological steps and identifying the primary goal of Danila's quest. Österberg does not include significant exploration of the bylina or bogatyr in her study.

\section{ENGAGING THE FOLK}

In his exploration of the role of the folk in the contemporary culture industry, Jack Zipes notes that historically the folktale has functioned as a uniting force for a community, 'bridg[ing] the gap in their understanding of social problems in a language and narrative mode familiar to the listeners' experiences' (1979: 6). Further, he highlights the dynamic nature of tales as 'each historical epoch and each community altered the original folk tales according to its needs as they were handed down over the centuries' (Zipes 1979: 8). The role of the folk in the production of contemporary culture has become an area of interest for many folklorists who are examining the ways in which popular culture incorporates folkloric elements to better engage audiences. Peter Narváez and Martin Laba describe folklore and popular culture as 'interdependent categories of cultural activity in modern society' (1986: 7). They also offer an explanation of the folklore-popular culture relationship that resonates with Propp: 'offer a means of rendering experience intelligible and graspable through recognizable forms that are both pleasing aesthetically and relevant in a social interactional sense' (Narváez, Laba 1986: 2). This understanding of the importance of folkloric influence on audience reception and understanding of a specific narrative is applicable not only to forms of mass media but to popular cinema. Several folklorists have begun to look at the role of folklore in film, or 'filmic folklore' as described by Juwen Zhang (Sherman, Koven 2007: 1). The use of the folk in contemporary contexts is not a new phenomenon, particularly during times of social volatility.

The integration of the folk into cultural productions is particularly evident throughout Russia's history. Gary Cox notes that as early as the 17th century it was common for authors to use the fairy tale formula to define their heroes, particularly their 'Russianness', in the face of the onslaught of Western values. This technique, Cox continues, 'enabled contemporary readers to connect their hopes for the future with their memories of the past' (1980:87). He 
argues that this folk plot structure became increasingly popular in the country and was 'virtually standard for all prose tales' (Cox 1980: 91).

The tradition of engaging folklore in literature continued into the 19th and 20th centuries. Numerous scholars have identified these trends in literary productions by authors such as Fyodor Dostoevsky, Nikolai Gogol, Nikolai Leskov and Alexander Pushkin. ${ }^{3}$ Katerina Clark notes that the practice of utilising the trope of the 'folk-epic hero' existed in part so authors could 'appropriate the semantic overtones of the medieval text; authors hoped in this way to conjure up the lionhearted hero who helps his fellow men (a bogatyr) or the truly dedicated champion of the faith (a saint)' (1981: 50). In her seminal exploration of the Soviet novel, Clark highlights the ways in which writers, journalists and politicians employed the ritual of the folk to create socialist realist heroes which would resonate strongly with Russia's history and reading audiences alike. She further notes that the inclusion of the folk not only helped define heroes in the thirties and forties, but helped to 'convey the new sense of reality' (Clark 1981: 151). In his survey of Russian popular culture, Richard Stites also focuses on the important role folklore played in the 1930s, with a particular focus on the use of folklore to spur Russian nationalism during times of significant upheaval (Clark 1981: 71).

In the contemporary context, Mark Lipovetsky identifies the ways postmodernist writers and filmmakers draw on those very socialist realist tropes to define "postsots' heroes. He notes that filmmakers often recycle socialist realist mythology not to reveal the genre's 'absurdity or violence', but to please 'the middle-aged generation for whom Socialist Realism is more associated with childhood memories.' ${ }^{4}$ Though he draws a clear line between the didacticism of socialist realism and the ambiguity of the post-sots works, Lipovetsky highlights

3 For a good overview of this topic, see Wigzell (2001:41). Also see Clark 1981: 46-67.

$4 \quad$ To illustrate his thesis, Lipovetsky (2004:358) examines another Balabanov film, War (Bойнa, Russia, 2002). the post-sots' engagement with 'traditional cultural models' (2004:376). Expanding on Lipovetsky's observations, Olga Mesropova describes the ways in which fairy tale subplots 'serve as the narrative core' of the immensely popular female-centred detective novels written by Daria Dontsova (Mesropova 2008: 113).

Like the cultural productions discussed above, the Brat films cinematise people's fears during a time of political and social upheaval. At the heart of Brat's success is its ability to resonate so deeply with its audience and to unite a community. Viewers' comments about the film on internet-based film forum Kinopoisk.com illustrate the intense connection they feel with the themes explored in the film and with Danila. User 'truten' notes: 'This film cannot be analysed. You can only feel and breathe it. It is simply about me, about us, specifically about those of us from the 1990s.' Another user, 'axm3d' sees the timelessness of the films: "The film is not for just one generation. The Brat films will be seen for a long time because the themes covered in them are, more than ever, relevant today.' Numerous contributors comment specifically on Danila's importance in the broader context of Russian identity. User 'Directorr' explains: 'It is not for nothing that the film is called Brat. Even though he is on screen, Danila Bagrov is like a brother to us. He has become one of us and a loved one to all in the country. He embodies the desires of millions of our fellow citizens in terms of good and evil, order and decency, and about what is lacking in our daily lives.' Finally, user 'Nabby 1404' casts the Brat films in the context of Russian folkloric legends: 'I would call this film a legend - maybe not a global one, but definitely a Russian one. Indeed, the film absolutely reflects our life without exaggeration; it shows our relationship with one another and with those around us.' (Kinopoisk.com)

Through viewers' comments, we see that, for many, Danila reflects the country's national values and embodies traits typically associated with conceptions of what it means to be a 'hero'. One critic has noted 
that Danila has become a 'real folkloric character' on par with other iconic Russian popular culture heroes such as Shtirlitz and Sukhov ('Последний герой’ 2002). These characters served to unite disparate groups of Russians during times of upheaval - a difficult task that Danila's character manages to accomplish with apparent ease.

Due to its immense popularity, Birgit Beumers classifies Brat as a 'blockbuster', a denotation given to films that reach a high level of popularity and mass appeal. She notes that one of the very reasons films often achieve such success is because they rely on folk culture in order to re-establish 'a known order' (Beumers 2003: 445). Balabanov's use of the folk in Brat (and later Brat 2) offered its weary audience a familiar formula and a predictable narrative. Discussing the importance of ritual and form in mass culture of the Soviet period, Clark notes that they 'provide a kind of shaping force to the energies that are most powerfully broad in the society; they are a focusing lens for cultural forces' (1981: 9). Indeed, Danila's journey as allegory for the country's post-Soviet transition is in part achieved in the films' attempts to define Russian heroism and identity in the face of the onslaught of Western materialism felt by Russians in the 1990s (represented in the first film by the presence of American music, McDonalds and US dollars and in the second by America itself). Balabanov accomplishes this by creating two films, and a hero, that are stylistically Western, but also distinctively Russian. Thus, in identifying with the film(s), the viewer can be reassured in his own daily struggles with the changes brought to Russia via the West - he can both embrace and reject aspects of Westernism and Russianism in an effort to define a third course for the post-Soviet era (Hashamova 2007: 58). Ultimately, Danila not only fulfils his individual quest of finding his 'self' and a place in the broader social consciousness, but also achieves the goal of slaying Russia's modern-day dragons (the Chechen, the mafia boss and the American businessman) and rescuing the Motherland.

\section{PROPP}

In 1928 Vladimir Propp published Morphology of the Folktale in which he proposed that an entire class of tales can be defined by their common structure based on thirtyone 'functions' and the actions of seven dramatis personae. While the title of Propp's book suggests a broader focus, he applies his morphological analysis specifically to the Russian wonder tale (or the 'fairy tale') which he defines as 'those tales classified by Aarne under numbers 300-749' (1968: 19). While a concise definition is never fully offered by Propp, he provides the following definition of the wonder tale based on his analysis of tales in Afanas'ev's collection:
A wondertale begins with some harm or villainy done to someone ... or with a desire to have some- thing $\ldots$ and develops through the hero's departure from home and encounters with the donor, who provides him with a magic agent that helps the hero find the ob- ject of the search. Further along, the tale includes combat with an adversary, a return, and a pursuit. (Propp 1984: 102)

Propp's work has been influential not only in analysing Russian wonder tales, but has been successfully utilised by scholars to analyse the structure of other categories of tales and folk tales of cultures different than Russia's (Lesinskis 2010: 41).

Propp's thirty-one 'functions' are described as denoting 'the action of the character from the point of view of its significance for the progress of the narrative' (1968: 74). Each of these functions unfolds in specific order, one out of another with 'logical and artistic necessity' (Propp 1968: 64). All functions are given a brief definition and a corresponding notational sign. In an effort to narrow the scope of the functions, each can be subdivided according to its specific manifestation. For example, the first major function, 'Absentation', is given the sign ' $\beta$ ', but can be subdivided into $\beta^{1}$ ('Person Absenting himself can be a mem- 
ber of the older generation'); $\beta^{2}$ ('An intensified form of absentation is represented by the death of the parents'); $\beta^{3}$ ('Sometimes members of the younger generation absent themselves') (Propp 1968: 26). The dramatis personae play essential roles in the development of the tale's narrative and are often 'stock' characters, given little depth or nuance. The seven personae identified by Propp are: the hero, villain, donor, helper, princess, dispatcher and false hero (Propp 1984: 79).

\section{THE BYLINA}

Before turning to a Proppian analysis of Brat and Brat 2, I will examine the ways in which Balabanov's depiction of Danila draws on the hero-characterisation in Russia's rich folk tradition. Danila's character fits well the definition of what E. M. Meletinsky calls the 'low hero' of the wonder tale who "occupies an inferior social position, is poorly dressed (a quality Danila's brother points out early on when he orders him to buy to new clothes), is scorned by those around him, and appears lazy and simpleminded. However, he unexpectedly performs heroic feats, or receives the support of magic forces and thus attains the goals of the tale' (Meletinsky 1975: 236). Propp's more technical description of the hero easily applies to Danila: 'The hero of the fairy tale is that character who either directly suffers from the action of the villain in the complication, the one who senses some kind of lack, or who agrees to liquidate the misfortune or lack of another person' (1984: 50). While this somewhat generic description could be applied to a wide variety of tales, I believe it resonated particularly deeply with a 1990s Russian audience eager for a heromodel for that tumultuous era.

Even more than the 'low hero' of the wonder tale, the bogatyr (богаmырь) of the Russian bylina is ideally suited for a modern retelling of the Russian epic as the bogatyri (plural) are "the standard bearers of the idea of Russia's invincibility, the people's guardians and protectors' (Volodarsky 1979: 164). The byliny (plural) are the epic tales from Russia's past. The hero of the bylina is the famous bogatyr, a larger than life character who embodies the Russian spirit and has endured in the cultural mindset as the quintessential model of Russian heroism. Referring to the importance of the bylina and its heroes in the Russian literary imagination, Faith Wigzell notes:
So well-known is the bylina in Russia today that its language forms a distinct sub-code of lit- erary Russian and as such may appear in all manner of literary works. No less important are the heroes, though here it is not so much the figures themselves who are the inspiration for literary characters as the qualities they embody, which are seen as quin- tessentially Russian: patriotism, strength, endurance and great capacity for drink. (2001: 41)

Katerina Clark notes that socialist realist discourse during the 1920s and 30s drew heavily upon the image of the bogatyr to define contemporary heroes, first in the pages of Правда and then in novels: 'The new man of action was not likened to a frontiersman ... but to the mythical knight of the Russian oral epic or bylina, the bogatyr ... bogatyr heroes abound in mid-twenties novels' (1981: 74).

As several scholars have noted, Balabanov makes the allusion to the bogatyri prominent with the display of a tapestry of Viktor Vasnetsov's well-known painting Богатырu, depicting the three most famous of this class of hero: Ilya Muromets, Dobrynya Nikitich and Alesha Popovich astride their loyal steeds (Larsen 2003: 507). (Figure 1) Though their analyses do not elaborate on this particular descriptive aspect of Danila's character, Jennifer Day and Mark Lipovetsky specifically link Danila with the bogatyr and Evgenii Margolit calls Danila 'an authentic knight' (Day 2005: 620; Липовецкий 2000: 58; Марголит 1998: 59).

By hybridising the wonder tale and the bylina, Balabanov is able to merge the structural clarity, entertaining journey-adventure 
plot and simplicity of the wonder tale with the hero-imagery and historical engagement of the bylina in a way that is extremely potent for audiences. While the wonder tale and bylina genres are indeed categorised as distinct and separate, Propp himself recognised that wonder tales 'are not a part inseparable' from other types of tales, and that 'plots often migrate from genre to genre' (1968: 79). In particular, Propp notes that the wonder tale is apt to absorb elements from legend and the bylina (1968: 93). Alex Alexander argues that similarities in 'structure and content' of the two genres indicate that the 'bylina evolved from the fairytale' (Alexander 1973: 7). Byliny are classified along many different lines, with those that overlap with the wonder tale often labelled as the 'fairy-tale type' (Alexander 1973: 14). In a collection of fairy tales, V. Bazanova includes fifty nine tales under the sub-heading 'Byliny of the fairy-tale type' (Базанова 1958: 519-520). She notes that these tales 'in their thematic relationship greatly remind one of fairy tales' (Базанова 1958: 5).

Like the bogatyr, Danila's status is often a complicated blend of qualities traditionally deemed 'good' and 'bad'. Lipovetsky has characterised him as a 'kind-hearted killer with the face of a child', a definition in line with what Propp describes as the complex nature of bogatyr morality (Липовецкий 2000: 55). Propp notes, '[i]n epic poetry all basic heroes are good and embody national ideals. Nevertheless, their behaviour is sometimes at variance with contemporary ethics ... The hero is the one that wins, irrespective of the means, especially if he defeats a stronger opponent' (1968: 28). Like the bogatyr, Danila is 'good' at his core, despite the fact that his black and white value system often leads to immoral acts. The softer aspects of Danila's character, drawn from the endearing wonder tale hero, along with his ultimate victory over a much stronger enemy, help to make his heroism appealing and ultimately acceptable.

\section{OTHER FOLKLORE IN BRAT}

The Brat films not only engage with the folk on a structural level, but include many other folkloric tropes which both compliment their structure and further familiarise the audience with the narrative. The name 'Danila' stands out immediately to a contemporary audience as anachronistic - a moniker that evokes the 'Prince Danila' or 'Danila the Luckless' of the folk world. ${ }^{5}$ This anachronism is highlighted by the hero's first appearance in the film: an ancient castle which serves as the backdrop for a music video shoot. (Figure 2) The setting evokes a medieval past populated by knights and damsels in distress. As is typical of the simplicity of the folk narrative, the viewer is given few details about Danila's background: he is physically non-descript, lacks the complexity of a fully-developed character and views the world in good/bad (us/them) binaries.

Trebling, another prominent feature of the wonder tale, is prominent in both films. In the first, Danila commits three hits prior to his final shootout with Kruglyi (he kills three men in this scene); he goes three times to the music store to search for Nautilas CDs; and there are three women in the story (his mother, Sveta and Kat). In the second film, he and his two friends visit the banya (баня, sauna) with three women; he develops relationships with three women (Saltykova, Lisa Jeffrey and Dasha); he is involved in three murders; and the action takes place in three cities (Moscow, New York and Chicago) (Larsen 2003: 506).

\section{A PROPPIAN READING OF BRAT AND BRAT 2}

Film scholars have also turned to Propp to analyse the structure of narrative cinematic productions. Scholars who utilise Propp's framework have noted a distinctive similarity between the formulaic outline offered by Propp and the universal narrative structure of classical Hollywood cinema productions

'Danila' appears in other folk works. Alexander notes: 'The commonest first name is Ivan, though others, such as Danilo, Fedor, and Fedot, appear' (1973: 26). The instances in folktales include 'Prince Danilo' (see Chadwick 1964: 173), 'Danilo Lovchanin' and 'Danilo Ignatevich and Maikhaylo Danilovich' (see Magnus 1967: 93, 110), and 'Danilo the Luckless' (see Balina et al. 2005: 79-84). 

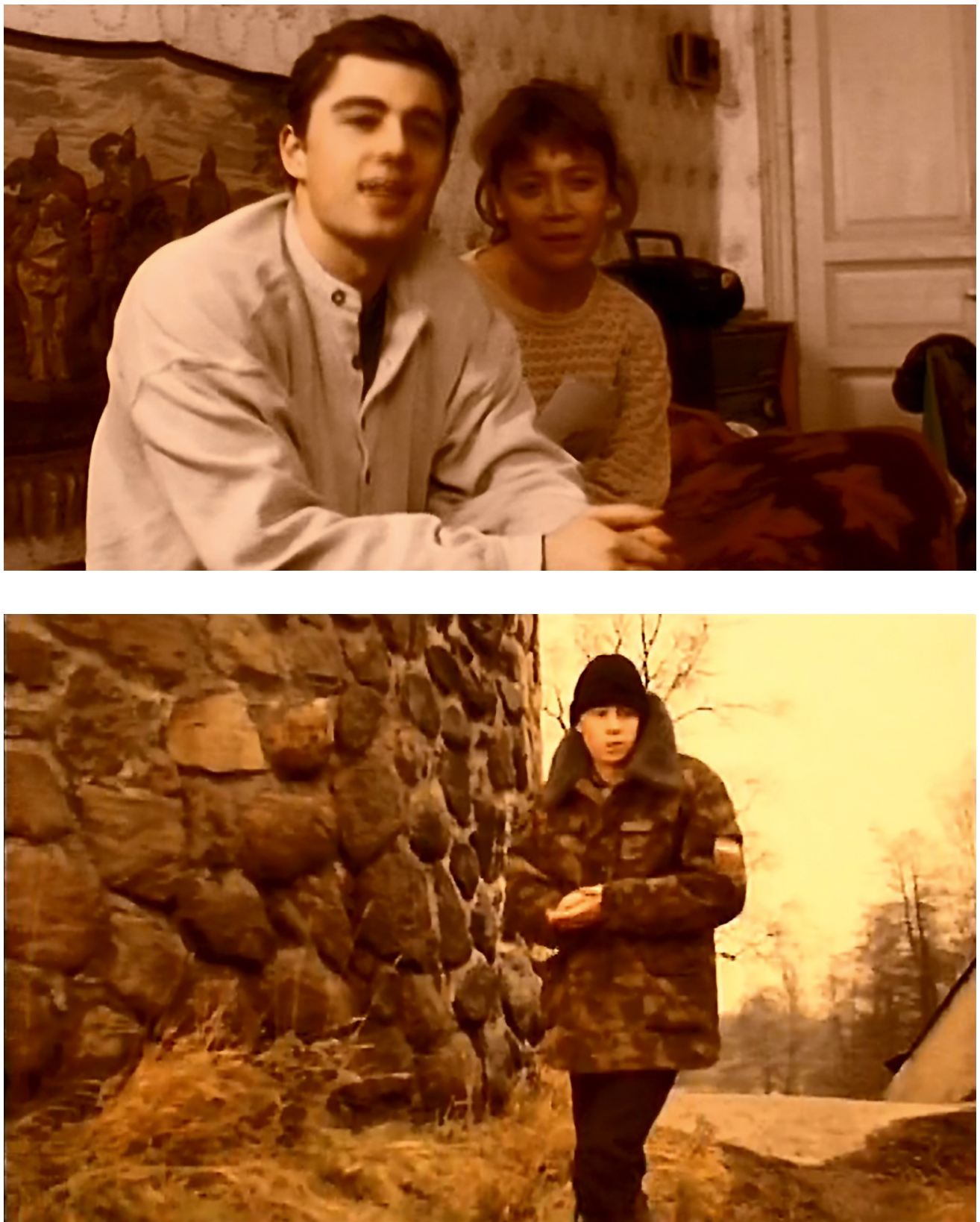

FIGURE 1.

FIGURE 2. 
(Lesinskis 2010). Peter Wollen's seminal 1976 article on Hitchcock's North by Northwest was one of the first to apply Propp to film (Wollen 1982). Subsequently, numerous films such as Adrian Lyne's Fatal Attraction (USA, 1987), Howard Hawks's To Have and Have Not (USA, 1944) and Brian De Palma's Carrie (USA, 1976) have been assessed according to Propp's morphology (Hala 1992, Fell 1977, Alexander 1979). These scholars have found Propp's framework to provide useful insight into the macro-structure of a film, adding another level of dimension to their film analysis. Annette Kuhn has noted that Proppian functions can serve to explore and differentiate between the story and plot in the film (Lesinskis 2010: 42). In Eugénie Zvonkine's Proppian analysis of Kira Muratova's The Sentimental Policeman (Чувствительный милиционер, Russia, 1992), she argues that the director's use of the folk allows Muratova to 'detach herself from the characters' inner world' (Zvonkine 2007: 144). This observation is particularly relevant to the Brat films as their rich cultural insights derive not from complex and three-dimensional characters, but from the circumstances and conditions in which they function. Janis Lesinskis also notes the Propp is particularly helpful in organising 'social ruptures' and 'anxieties' - an observation relevant to the Brat films, which were produced during the volatile decade following the collapse of communism (Lesinskis 2010: 65-66).

The application of Propp is not without controversy. Opponents of Propp are critical of the widespread use of his structural outline, which was based on only a small class of Russian tales. They also note the shortcomings of structural approaches which strip texts of their details to focus only on stock structural elements that could be endlessly manipulated to almost any text (Chatman 1980:15-17). Finally, feminist, postcolonialist and linguistic scholars have noted the problems associated with reductionist elements in Propp's approach which limit the agency of both characters and audience within a 'closed text' (Lesinskis 2010: 38).

David Bordwell is particularly critical of the use of Propp in film analysis, emphasis- ing that scholars too readily apply uniquely Russian models of the wonder tale to Hollywood films. He sees it as unreasonable to believe that 'a method derived for the analysis of oral narratives of a pre-feudal era hold good for a modern medium developed in a capitalist economy and a mass society' (Bordwell 1988: 11). While Bordwell makes important points about the application of Propp to such an indiscriminate range of cinematic and television productions, the wide use of Propp in film analysis and the insights gleaned from the Proppian critiques noted above illustrate the utility of this approach (Lesinskis 2010). Scholars such as Peter Wollen and Jim Hala successfully illustrate that a structural analysis of a film can reveal important details such as patterns of action, stock functions of characters and narrative organisation that provide another layer of meaning to films. Examining Brian De Palma's Carrie through a Proppian lens and connecting audience reception to the narrative's folkloric roots, Russian folklorist Alex Alexander notes that "one of the reasons for [the film's] immense popularity is that it is a fairy tale' (1979: 282).

Bordwell's criticism also carries less weight when applied to a Russian film fully steeped in the appropriate cultural context that he sees lacking in non-Russian films. The persistent use of the folk in contemporary Russian cultural productions also indicates the usefulness of viewing Balabanov's films through a Proppian lens. In terms of the Brat films, their affinity with a Western style of blockbuster filmmaking and intense engagement with Russian cultural traditions, values and narrative genres, makes Propp's work particularly relevant as an analytical tool.

\section{BRAT}

The dramatis personae in Brat are: Danila (hero); Kruglyi (villain); World War II veteran (donor); Hoffmann and Kat (helpers); Sveta (princess); Mother (dispatcher); and Viktor (false hero). In both Brat films, the characters are often called by their nicknames (i.e. the Chechen; Kruglyi [Roundy]; Nemets [the German]; Tatarin [the Tatar]; the Fascist), 
which reinforces their roles as stock characters whose primary purpose is to assist in the hero's journey. Yana Hashamova notes that in Brat 2, as in the first film, characters 'lack individuality or psychological substance and are presented on the screen as ciphers' (2007: 51).

In addition to a continuity of functions and dramatis personae, Propp notes other features of the wonder tale. Most important are the tale's 'auxiliary' functions, or the 'elements upon which the course of the action is built', but that are not essential for the plot development (Propp 1968: 71). In the Brat films, there are several events in Danila's quest that are important, but nevertheless asides to the primary trajectory of the film. For example, in Brat, Danila's encounter with the Chechen men on the tram; the party he attends with Kat; Sveta's rape; and his obsession with the musical group Nautilus Pompilius (Larsen 2003: 505; Österberg 2006: 49-52). These scenes have received attention from scholars who rightly point out their significance to the films' negotiation of the central issues of 'patrimony, paternity and patriotism' (Larsen 2003: 494). I also believe that these auxiliary events in the film represent Balabanov's filmmaking creativity - the real sites for exploring his auteur style and stand out even more in the film given the formulaic structure of the narrative. While the auxiliary events in Brat provide the film's important cultural insight, those in Brat 2 are not only fewer in number, but carry much less symbolic weight.

Propp notes that all tales begin with an 'initial situation' (a) in which the future hero and members of his family are enumerated. In Brat, this is established by the series of brief episodes, each introducing a member of the family or Danila himself, each terminating with a cut to black. Also established during these introductory scenes are the first, second and third functions: 'Absentation ( $\beta$ )'; 'Interdiction ( $\gamma$ )'; and 'Violation of the Interdiction ( $\delta)^{\prime}$. Brat contains two absences marked by the 'death of a parent $\left(\beta^{2}\right)$ ' (Danila's father) and a 'missing mem-

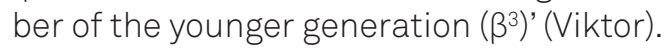
The interdiction is an inverted form of this function $\left(\gamma^{2}\right)$. Rather than the hero receiving an interdiction not to do something, he is instead ordered to complete a task ("bring breakfast out into the field') or go somewhere ('take your brother to the woods') (Propp 1968: 27). The fulfilment of this command then substitutes as the violation of the interdiction. Thus, Danila's interdiction is delivered by his mother who orders him to seek out his brother in St. Petersburg.

The next four functions ('reconnais-

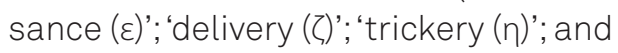
'complicity $(\theta)$ ') establish the villain and depict his illicit actions ('villainy (A)'). The former functions mark the end of the prologue portion of the tale while the fifth launches the story's action. Kruglyi, or Roundy (named for his bald, round head), is a mafia leader and the unquestionable villain of Brat. He speaks almost entirely in proverbs, infusing the film with the familiar language of the folk, the 'Zhili byli' ('Жили-были', 'Once upon a time'), of the traditional tale.

The functions involving the villain are fulfilled in one of the opening scenes in which Viktor negotiates a fee to murder Kruglyi's enemy, the Chechen, a mafia boss who controls the local rynok (pынок, market). ${ }^{6}$ As with the interdiction, the reconnaissance function in Brat takes the inverted form $\left(\varepsilon^{2}\right)$ marked by 'the intended victim question[ing] the villain' (Propp 1968: 28). Viktor demands Kruglyi pay him twenty thousand dollars for the hit and that he deliver half of the cash up front. The subsequent reaction is also inverted ('information gathering evokes a corresponding answer $\left.\left(\zeta^{2}\right)^{\prime}\right)$ when Kruglyi responds by agreeing to Viktor's terms. (Figure 3) However, his reticence betrays both his mistrust of Viktor and his plan to eliminate him once the hit is complete. This action fulfils the villain's 'employing other means of deception $\left(\eta^{3}\right)$ ' to appease the intended victim (Viktor).

6 It is significant that the first 'dragon' Danila is tasked to slay is given the epithet, 'The Chechen'. Several scholars have observed that in the traditional bylina (and even the wonder tale), the foreign enemy, most notably a Chechen or Tatar, is the intended target for the hero to destroy. America (Westernisation) also looms large as an allegorical enemy in Brat and becomes the literal foreign enemy to be defeated in Brat 2 (Blakey 1923: 528). 
Viktor's commitment to carrying out the hit fulfils ' $\theta$ ' ('the victim submits to deception and thereby unwittingly helps his enemy') (Propp 1968: 30). Viktor departs from Kruglyi's office unaware of the peril he has placed himself in while Kruglyi commands his men to keep an eye on Viktor, with the implication that he will be punished for his insubordination. This declaration fulfils 'an order of a murder' $\left(A^{13}\right)$. The subsequent functions will shift the focus of the narrative back to the hero.

The next phase of the journey (launched by 'A'), begins with the demonstration of the hero's lack of, or desire for, something (a). These lacks or desires will be liquidated at the end of the quest. Propp (1968:36) emphasises that the hero either sets out searching specifically to fill these voids or that the lack is revealed in the process of the quest. Balabanov, adhering to the latter model, provides the viewer with several motivations for Danila's quest. While Danila's lack of a father launches his initial quest for his brother, and serves as a catalyst for the action of the films, this task is essentially completed early in the film when he locates Viktor, indicating that his journey is about something larger. Danila's abandonment of Viktor at the end of the first and second films further indicates that the 'Brat' or 'Bratstvo' ('Бpamcmвo', 'brotherhood') that Danila is searching for is more symbolic than genetic.

Perhaps the more important lack Danila seeks to fill is his lack of human connection, or place in the world: he is a young man in search of his 'self'. This deficit of human connection in the chaotic 1990s is something that many Russian viewers could closely identify with. Clark notes that the paths of heroes in Soviet novels often focused on leading them toward social integration and were framed around negotiating the tension between the individual and the collective. She describes this tension as the 'spontaneity/consciousness dialectic', which casts spontaneity as a 'primitive social form' focused on the individual while 'consciousness' is the ultimate force operating in the 'best interests of society' (Clark 1981: 16).
She also notes that this tension between the individual and the collective is not simply at the heart of socialist realist novels, but is "one of the key binary oppositions in Russian culture' (Clark 1981: 20).

Balabanov is able to resurrect this quest for consciousness, for integration into something broader than the self in his portrayal of Danila's journey from isolated, directionless boy to national hero, surrounded by 'brothers' and others devoted to the homeland. ' His lack of connection and consciousness initiates several subplots in the film including Danila's relationship with his moral adviser Hoffmann, his friend Kat and lover Sveta. These elements of the films' plot are strongly associated with the adolescent's 'desire to follow other models for identification but at the same time be his/her unique self' (Hashamova 2007: 48).

In addition to the more complex lack explained above, Danila is also lacking a bride and a kingdom, common motivating forces in the wonder tale. His search for these two things serves as a subtext throughout both films and is ultimately resolved in Brat 2 when he books a date with the pop icon Irina Saltykova and returns to Russia, a kingdom which has had its glory restored thanks in part to Danila's heroic actions in America.

After the hero's lack is exposed, the next function for Propp is the 'mediation' or 'connective incident' (B) in which a misfortune is made known or the hero is approached with a request or command and is then dispatched. Brat contains two variations of this function. The first, 'Misfortune is announced ( $\left.B^{4}\right)$,' takes place when Viktor pleads with Danila to help him with the murder of the Chechen, explaining that not only is his life in danger if the Chechen runs the market, but that all Russians will be 'smothered' if the Chechen continues to operate. This is followed by 'The Hero is dispatched directly $\left(\mathrm{B}^{2}\right)$ ' when Viktor sends

Susan Larsen (2003: 511) highlights the more complex aspects of Danila's understanding of this national consciousness, emphasising the link to the Stalin era 'Great Family' collective rooted in patrilineal masculinity. 

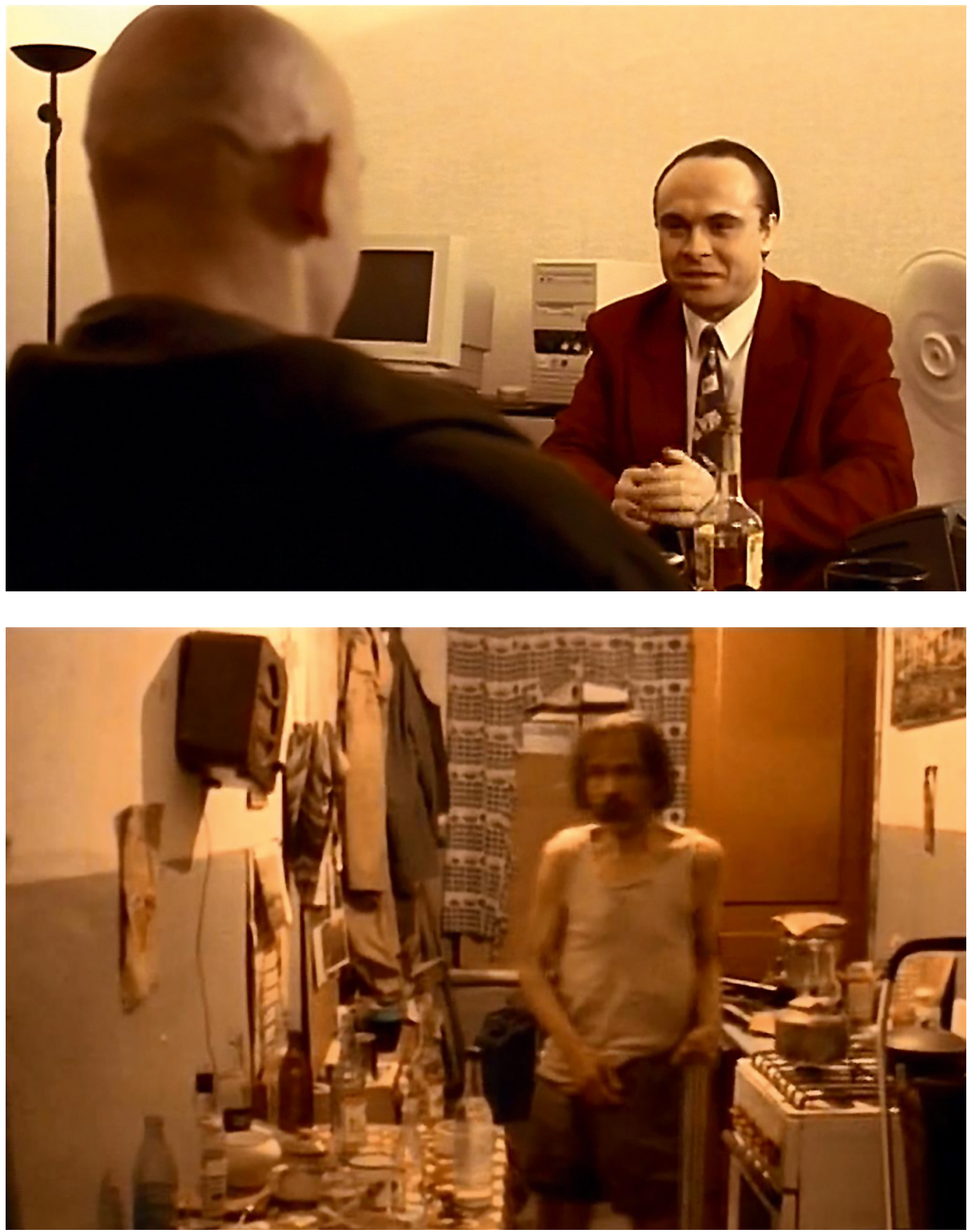

FIGURE 3.

FIGURE 4. 
Danila to carry out the assassination of the Chechen (Propp 1968: 37). 'B' marks a critical point in the narrative: "the arrival of the hero' (Propp 1968: 36). Though the viewer encountered the future hero in the prologue, his role is confirmed during this phase.

Danila emerges at this point as the undisputed hero of the tale while Viktor's heroic possibilities are quickly negated when he deceives his younger brother, thus becoming the tale's 'false hero'. The next functions, 'Beginning counteraction (C)' and 'departure $(\uparrow)^{\prime}$ are fulfilled when Danila accepts Viktor's pleas for him to undertake the murder of the Chechen and departs to fulfil this promise (Propp 1968: 39).

It is typically during the 'departure ( $\uparrow)^{\prime}$ stage of the tale that the hero will come into contact with two significant personae: the helper and the donor. It is thus appropriate that at this point Danila receives assistance from Hoffmann and meets the future donor (the World War II veteran). Though Danila has already encountered Hoffmann, the first time he employs him in the helper capacity is to find an apartment to use as a base camp for his counteraction against the Chechen. While the helper can aid in the hero's quest in multiple ways, Propp notes that his most important attribute is 'his prophetic wisdom' (Propp 1968: 83). Hoffmann is indeed Danila's moral anchor. ${ }^{8}$ His wisdom is offered early in the film when he advises Danila to beware of the dangers of the city. He warns: 'The city? The city is an evil force. And the larger the city, the stronger it is. It sucks one in. Only the strong can extricate oneself from it.' Though Danila ultimately succumbs to the city, Hoffmann appears frequently, offering guidance, wisdom and advice at critical junctures in the hero's quest.

The next three functions of the tale: 'The first function of the donor' (D); 'hero reacts' (E); and 'Provision or receipt of a magical agents' (F) can also be grouped. Brat offers multiple versions of the first function 'D': 'hero is tested' ( $\left.D^{1}\right)$; 'hostile

8 Österberg (2006: 12-13) provides interesting analysis of the character as an allusion to the German wonder tale author, E. T. A. Hoffmann. creature attempts to destroy hero' $\left(D^{8}\right)$; and 'hero is shown a magical agent which is offered for exchange' ( $\left.D^{10}\right)$ (Propp 1968: 40). The donor occupies an important role in the wonder tale as he provides the hero with the magical agent that will help him complete his quest. In Brat, the donor is the unlikely character of the drunken, wiry old veteran who lives in the communal apartment in which Danila plots his first hit. (Figure 4) The choice of this withered alcoholic as the donor also provides commentary on the fate of even the 'greatest generation' of men in post-Soviet Russia and the reduction of these heroes of old to peddlers of weapons for the new generation of killer-heroes. The first time he enters the apartment where the old man lives, Danila is shown the gun that will eventually serve as the magical agent $\left(D^{10}\right)$ that will allow him to complete his ultimate task: slaying Kruglyi.

After Danila kills the Chechen, he is shot by Kruglyi's hostile men $\left(D^{8}\right)$. The second function (E) is fulfilled when Danila 'survives the test ( $\left.E^{1}\right)$ ' by successfully carrying out the hit on the Chechen for Viktor and shooting one of Kruglyi's men, thus saving himself 'from an attempt on his life by employing the same tactics used by his adversary' (E') (Propp 1968: 42-43). In the Brat films, the 'DE' grouping, the process of being tested and surviving, repeats itself six times (trebling) until Danila is finally able to obtain the magical agent. He has two sets of trials (each made up of three parts): the first represented by the three rounds of murder he commits before finally assassinating Kruglyi and the second set of trials associated with his quest for social connection. The latter three (the excursion to the club with Kat; the party attended by Nautilus' lead singer Vyacheslav Butusov; and Sveta's rape) represent some of the most important auxiliary functions in the film. ${ }^{9}$

9 Kat is an involuntary helper who shows the hero the path to the underworld. She lures Danila off of his path, introducing him to acid, taking him to a Westernoriented club, then to an after-party where she sleeps with him and steals his wallet. This party is about sex, drugs and American music which are all repulsive to Danila (though he willingly participates in the former two). His negative attitude reinforces his ethnocentric and nationalist affinities. 
These trials are pivotal subplots for the film's action and opportunities for Balabanov to make his artistic mark, but they do not significantly influence the trajectory or outcome of Danila's quest. It is ultimately the initial encounter with the donor that makes it possible for Danila to fulfil the next function, 'F', when he purchases the gun from the old man for two hundred dollars (' $F$ ": the agent is sold and purchased') (Propp 1968: 44).

The next function, 'spatial transference (G)', is carried out when, after reconfiguring the old man's gun and ammunition into a more compact and deadly tool, Danila is transferred to Viktor's home. Here he 'climbs a stairway $\left(\mathrm{G}^{5}\right)$ ' and enters the apartment. Danila then participates in a 'struggle' in which the "hero and villain engage in direct combat (H)' (Propp 1968: 51). Danila has a shootout with Kruglyi and his men, killing all but one bodyguard. The murder of Kruglyi achieves 'victory (I)' (Propp 1968: 53). Specifically, the murder before the villain has a chance to draw his weapon, satisfies ' $5^{5}$ ' ('villain is killed without a preliminary fight'). In a rare instance of the functions falling out of order, Danila obtains Kruglyi's briefcase filled with American dollars and is thus 'branded', receiving a contemporarily appropriate suitcase full of money instead of the folkloric 'ring or a towel $\left(\mathrm{J}^{2}\right)$ ' to mark his victory (Propp 1968: 54). Propp's next function, "[i]nitial misfortune or lack is liquidated' $(K)$, marks the peak of the narrative. Danila liquidates the lack of a father-figure by rescuing Viktor and affirming their brotherly bond. (Figure 5) This task is accom-

\footnotetext{
A stark contrast is drawn between the party Danila follows Butusov into and the one at the club. Here he confronts a part of Russian culture from which he stands removed, but is drawn to. Danila silently observes the young Bohemians relaxing in an intellectual's apartment - singing Russian songs and playing the guitar. He is a detached voyeur, mesmerised by the appeal of this very 'Russian' cultural experience (Larsen 2003: 507).

After Sveta's rape, Danila finds her intoxicated in her kitchen, bloodied and singing. He does not comfort her and his one emotional outburst stems from wounded pride, not empathy. For him, Sveta represents the motherland: her defilement is the country's and delivers a blow to both his masculinity and his status as hero a fall from grace that is emphasised, as Larsen notes, by the 'Bogatyri' tapestry in the background of the rape scene (2003: 507).
}

plished as a 'direct result of his preceding actions $\left(K^{4}\right)$ '. The acquisition of the suitcase full of money also makes Danila very rich, thus satisfying, 'utilization of the magical agent to overcome poverty $\left(K^{6}\right)$ '.

Despite having just slain the dragon, Danila's journey is not complete. He warns Viktor to leave town, to return to their mother in order to avoid retaliation. He himself prepares to leave town - first returning (' $\downarrow$ ') to Sveta's apartment to rescue her. It is here that Danila encounters her angry husband who attempts to start a fight with Danila and banish him from the apartment ('pursuit (Pr)'). After shooting her husband, but failing to lure Sveta away, Danila leaves the apartment, walks to the edge of the city and, emerging from a snowy forest, is picked up by a passing truck driver ('rescue (Rs)') (Propp 1968: 56).

Many tales end here, with the hero returning home after having completed his quest. However, as Propp observes while 'a great number of tales end on the note of rescue from pursuit ... this is far from always being the case. A tale may have another misfortune in store for the hero: a villain may appear once again' (Propp 1968: 58). The new adventure is launched by another villainous act, prompting a 'move' (Propp 1968: 59). For Propp, the second tale essentially repeats the functions of the first through the function ' $G$ ' ('the hero is brought or transported to the location of the object of the quest'), at which point a new set of functions follows (Propp 1968: 59).

There are several elements at the end of Brat which predict that Danila will continue his adventures. The most obvious is his physical departure for Moscow. The forest represents the symbolic site of transition in the folk tale and the long, isolated road Danila and the driver navigate marks a clear shift away from the gleaming waterways of St. Petersburg. Morphologically, at the end of Brat, Danila has not completed the heroic cycle as he has not liquidated many of his lacks. Specifically, his journey of self-discovery is not yet complete as he still seems to lack any real consciousness or human connection. By the end of the film, 
he has become distanced from Hoffmann. This distance is reinforced when Danila attempts to give his wise helper a stack of Kruglyi's dollars, indicating his failure to connect with Hoffmann's values. He fails to establish a lasting connection with Kat who gladly accepts the money Danila offers her and skips out of the McDonalds where they have met immediately after the transfer. Danila also leaves Viktor, sending his brother back to the provinces. Finally, he lacks a bride, the result of his inability to rescue Sveta. These outstanding lacks strongly indicate that another cycle of adventure is essential to affirm his heroism.

\section{BRAT 2}

As Propp indicates is typical of wonder tale sequels, the first part of Brat 2 follows closely the formula of the first film. Instead of stumbling into a music video shoot, Danila walks onto the set of a television commercial; the opening scene of Brat in which Danila's mother extolls Viktor's virtues is replaced with her chastising Viktor and praising Danila (she orders the elder son to Moscow); Danila's background is still mysterious - while he now admits to serving in Chechnya, he makes the dubious claim that he is a medical student. His appearance and naïve schoolboy attitude remain intact, though he leads a more public life, appearing on television to discuss his heroic military service with his two buddies. These friends, Ilya and Mitya, establish Danila as part of a trio (trebling) and reinforce his nationalistic, rather than biological, understanding of 'brotherhood'. As in Brat, the roles of the dramatis personae are occupied by archetypal characters whose actions serve to reinforce $\mathrm{Da}$ nila's heroic quest. The dramatis personae in Brat 2 are: Danila (hero); Mr. Mennis, the American (villain); the Fascist (donor); Ilya and Lisa Jeffrey ${ }^{10}$ (helpers); Dasha and Irina Saltykova (princesses); Mitya (dispatcher); and Viktor (false hero).

10 A recent interview with the actress Lisa Jeffrey, who plays a character by the same name in Brat 2 reveals her understanding that the first film was so successful because Danila's character 'ha[d] come to encapsulate their need for a new heroic icon' (White 2014).
The villain in the second film emerges as an American, Mr. Mennis, who is conducting shady business in Moscow with an equally corrupt Russian banker. Mennis is linked with a group of Ukrainian mafia men who are not only producing snuff films in which Russian girls are raped and killed on camera, but are extorting money from Mitya's brother, an NHL player in Chicago. Mitya, a guard at the bank, pleads with his boss to discuss his brother's issues with Mennis - a plea for which he is murdered. Mitya's death serves as the catalyst for Danila's second adventure-quest, sending him to America to take on the Ukrainian mafia.

Danila departs for America only after a dramatic fire fight with the Moscow-based gangsters, aided in his pursuit by llya and the recently arrived Viktor. The three obtain their cache of weapons from the Fascist, a wiry young man who believes that Russia is in a constant state of war (a mantra Danila embraces). After successfully defeating the gangsters, Danila and Viktor acquire fake documents (magical objects) and set off for America.

Danila's arrival in the United States marks the 'move', which Propp notes is common in the wonder tale when a second journey is begun by the hero (Propp 1968: 58). As the first of the sequel's functions, 'the hero, unrecognized arrives home or in another country (o)' indicates, Danila's arrival in New York goes unnoticed as he easily avoids the group of thugs waiting for him in Chicago, his expected destination (Propp 1968: 60). The appearance of the hero in the new kingdom is followed by the next morphological step, 'unfounded claims (L)', in which the false hero presents himself (Propp 1968: 60). Viktor immediately reaffirms this role. His adventures are increasingly distant from Danila's and serve as a comic foil to his brother's high-morality quest. Unfortunately, though entertaining on some level, Viktor's character becomes irrelevant to the second film's main plot, his adventures degenerating until he becomes the fool, a stereotyped hybrid between a 'New Russian' Al Capone and the corner pimp. 

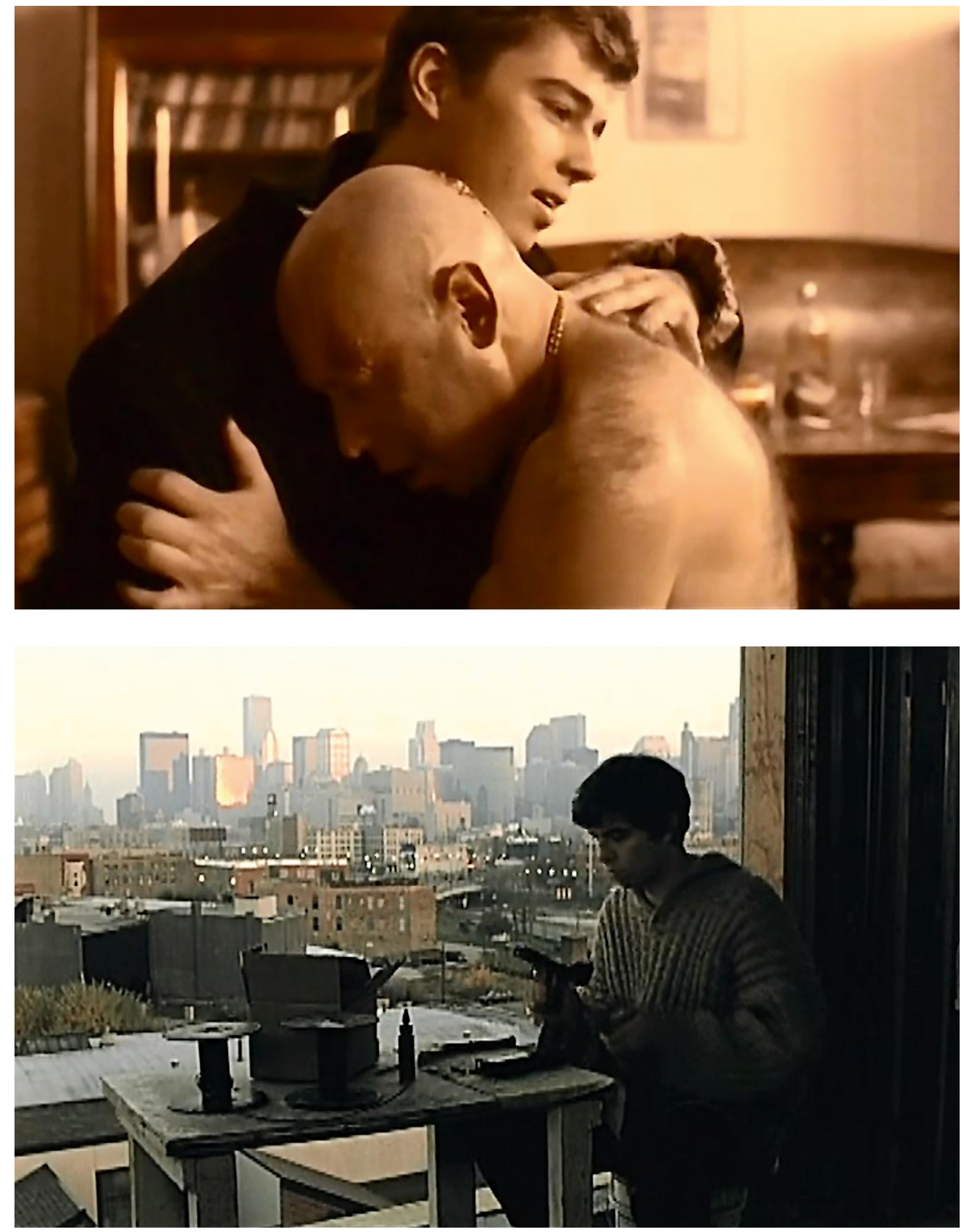

FIGURE 5.

FIGURE 6. 
Upon Danila's arrival in Brighton Beach, he is duped by a Russian car salesman who sells him a lemon which leaves him stranded in Pennsylvania. In another parallel with the first film, Danila is picked up by an amiable truck driver, Ben, who takes him under his wing and drives him to Chicago. Once there, he offers to further help Danila by 'getting him a girl'. Danila refuses the offer only after he realises that the prostitute who approached their truck, the bald-headed Marilyn, is actually a Russian woman, Dasha. Horrified by the presence of a Russian woman turning tricks on the streets of Chicago, especially under the control of an African-American pimp, Danila is compelled to rescue her. Though Danila has journeyed to America to avenge Mitya's death and aid his brother, it is the rescue of Dasha ${ }^{11}$ that becomes the primary goal of his quest and represents the next morphological step, 'difficult task (M)' (Propp 1968: 60).

Unlike the detailed functions in the first portion of the hero's journey, those defined by Propp in the second are much broader, often unconcerned with the steps along which tasks are completed, focusing instead on the big picture achievement of goals. Thus, it is already in the next step of the morphology that the 'difficult task' is resolved in 'N' ('solution') (Propp 1968: 62). After several encounters with Dasha's pimp and a repetition of Danila's methodical weapon-making process featured in the first film (this time he crafts a gun using just an old chair) (Figure 6), he rescues Dasha, shooting down her captor and his cohorts in a stairwell. Danila also resolves his other task: avenging Mitya's death and reclaiming his brother's money - Danila has little interest in the latter. The film includes the resolution of this task as an aside, subordinating it to Dasha's rescue. Nevertheless, empowered with the 'truth', Danila

11 The prostitute rescue plot is a resurrection of 19 th and early 20 th century tropes. Unlike in most of those stories, Danila is successful in his attempt to 'save' Dasha and return her to the safety of Russia, affirming his masculinity and Russia's superiority. Lipovetsky (2000: 59) observes that Dasha is reminiscent of the fallen women characters from Soviet literature who, finding themselves in the capitalist West, were forced into prostitution. avenges his friend's murder by ascending the fire escape of the skyscraper in which Mennis works, sharing a shot of vodka with him and then reclaiming the money extorted from his friend's brother. (Figure 7) In a monologue delivered to the terrified businessman, Danila describes his guiding moral principle. Asking Mennis rhetorically from where he draws his power, Danila says that he believes that power is in the truth ('sila $\mathrm{v}$ pravde,' 'сила в правде') and that whoever is correct/truthful is the most powerful. Danila contrasts this belief with what he sees as the American conviction that the source of power is money. This moment of the film, indeed Danila's quote, 'sila v pravde', is one of the most cited of the film with multiple YouTube clips devoted to capturing Danila's philosophical declaration. The quote, along with images from the film, also appears in several internet memes and on fan posters.

After the killing of Mennis and her own rescue, the previously cynical Dasha acknowledges and praises Danila's heroism, fulfilling the next function 'recognition (Q)'. The subsequent function, 'false hero or villain is exposed (Ex)', is fulfilled when Dasha identifies Viktor an 'ass' (kozel, козел), unworthy of Danila's loyalty (Propp 1968: 62). His false heroism is reinforced when he is arrested (for murdering a mafia man) after a standoff with the police. As Viktor cowers in an abandoned house, Danila and Dasha simply stand amid the crowd of onlookers. This time Danila does not forgive Viktor for his recklessness, but instead watches the action passively. Lipovetsky notes that Danila abandons Viktor largely because the older brother has been taken in by the perceived American value of selfishness and worship of money (Липовецкий 2000: 57).

The last three functions in the film: 'transfiguration (T)'; 'punishment (U)'; and 'wedding (W)' verge on the absurd (Propp 1968: 62). In order to elude the mafia, Danila and Dasha don disguises at the airport. Enlisting Ben's help, the two emerge from a shiny 1930s era Rolls Royce in their attire from the same decade. Danila wears a fedora, double breasted suit and wide tie while Dasha dons a bobbed wig and thick fur coat. 
BALTIC SCREEN MEDIA REVIEW 2015 / VOLUME 3 / ARTICLE
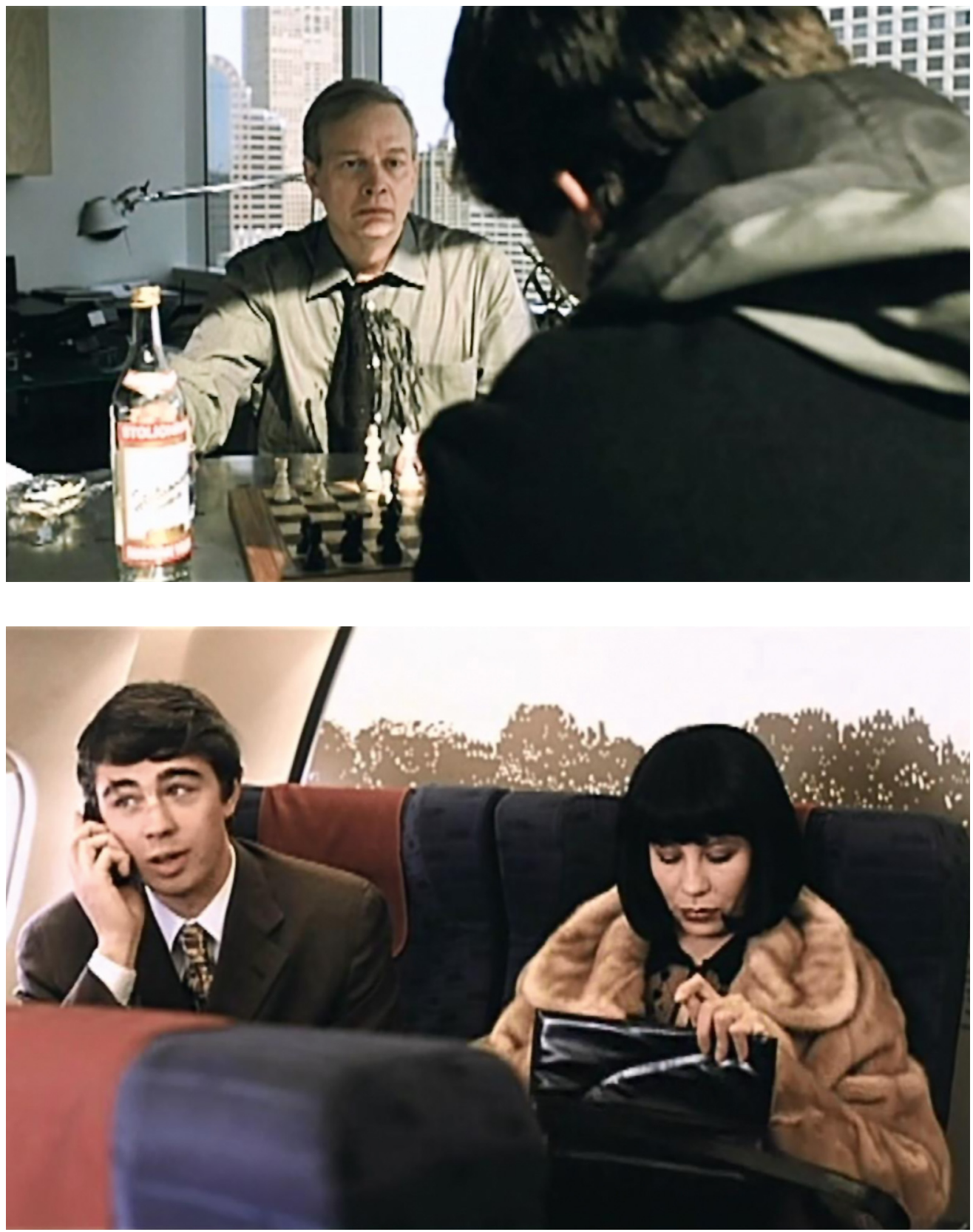

FIGURE 7.

FIGURE 8. 
These new markedly conspicuous garments somehow manage to conceal their identities from the thugs awaiting them in the terminal, allowing them to whisk past the bumbling Ukrainians and through security. These costumes also fulfil function ' $\mathrm{T}$ ' ' (the hero puts on new garments') (Propp 1968: 63).

' $U$ ' ('Villain is punished') is satisfied when Dasha, told that she cannot return to America because she violated the terms of her visa, extends her middle finger to the flight agents as she boards the Moscowbound Aeroflot plane. Her graphic signal of disdain for America is the punishment delivered not only to the flight crew, but the country itself. America is held responsible for every amoral act that occurs within its borders including Dasha's trafficking into the sex trade, the flourishing of the mafia, and the worship of money. 'America' is revealed as the primary villain of both films, defeated at last when Danila rescues Dasha, symbolically saving Russia and returning to his homeland (rodina, родuнa) as not only the bearer of moral superiority and truth, but with his potential bride awaiting him (he makes a date with Irina Saltykova via cell phone as he boards the plane) ('W') (Hashamova 2007: 55). (Figure 8) It is only upon the completion of this final function that Danila's quest, begun in the chill of St. Petersburg, is complete.

\section{CONCLUSION}

Balabanov's film reinforces the folkloric associations with its hero not only through plot details, allusions and familiar tropes, but with a narrative structure rooted in Russia's folk traditions. This multi-faceted approach to supporting the film's narrative with a framework that adheres so closely to Propp's makes the film even more accessible and historically relevant to viewers. It is not only the casting of the folkloric hero that is important in Brat, but the narrative morphology itself which so effectively frames the films' messages about Russia's identity, past, present and future.

The lack of judgment passed on Danila in the films liberates the Brat films from Soviet didactics, but nevertheless allows their hero's actions to be interpreted as part of a legitimate, if not admired, heroic ethos in Russia, reinforcing the values his character promotes: patriarchy, violence and the extermination of anyone who is not 'nashi' ('Hauu', 'ours'). Hashamova observes that the amoral elements of Danila's character are framed by the director simply as a part of the transition process, part of Danila's adolescent angst, thus redefining extreme violence as 'acceptable and even necessary' (Hashamova 2007: 48). Cox saw the same combination of an avoidance of didactics and embracing of heroic models in the 17th and 18th centuries: the readers 'wanted entertainment ... Yet ... this group sought a literary cultural hero, a figure who could represent their own hopes for success in an exaggerated, but not altogether unrealistic, way' (Cox 1980: 86).

In the Brat films, Danila offers a flawed, yet relatable hero, who not only promotes Russian values, but whose journey offers a black and white interpretation of the world and an escapist adventure to an audience steeped in the ambiguity and unpredictability of a rapidly changing post-Soviet landscape. Like the heroic, but not always good bogatyr, Danila is embraced as an unquestionable hero. The audience seems to admire, or at least understand, him precisely because he is wary of 'others', puts America in its place and seeks to protect Russian ideals and new models for Russian masculinity (Hashamova 2007: 48; Larsen 2003: 493). A sign that the value system promoted by the films still resonates with a contemporary Russian audience was revealed in a recent interview with current President Vladimir Putin. Discussing the crises facing the country, particularly Russia's position vis-à-vis the West, Putin, without making any explicit reference to the Brat films, reassured his audience that '[w]e are stronger because we are right. Power is in the truth ['сила в правде]]' ('Интервю' 2014). This almost verbatim reiteration of Danila's monologue (delivered by Balabanov's hero just prior to exterminating the American businessman, a metonym for America itself) is a key example of the continued relevance of Balabanov's films and also of the echo chamber of politics, popular culture and nationalist speech in contemporary Russia. 


\section{REFERENCES}

Alexander, Alex E. 1973. Bylina and Fairy Tale:

The Origins of Russian Heroic Poetry. Paris: Mouton. Alexander, Alex E. 1979. 'Stephen King's Carrie A Universal Fairytale'. - Journal of Popular Culture XIII, 2, 282-288.

Balina, Marina; Goscilo, Helena; Lipovetsky, Mark (eds.) 2005. Politicizing Magic: An Anthology of Russian and Soviet Fairy Tales. Evanston: Northwestern University Press.

Базанова, В. (ed.) 1958. Былины. Том 2. Москва: Гос. изд. чуд ожесвенной литературу.

Beumers, Birgit 2003. 'Soviet and Russian Blockbusters: A Question of Genre?' - Slavic Review 62, 3 , 441-454.

Birchenough, Tom 2000. "'Brat” Sequel Guns for Global Visibility.' - Variety $378,12,20$.

Blakey, Kate 1923. 'Early Russian Folk Epics.' -

The Slavonic Review 1, 3, 525-532.

Bordwell, David 1988. 'ApProppriations and ImPropprieties: Problems in the Morphology of Film Narrative'. - Cinema Journal 27, 3, 5-20.

Chadwick, N. Kershaw 1964. Russian Heroic Poetry.

New York: Russell \& Russell.

Chatman, Seymour 1980. Story and Discourse:

Narrative Structure in Fiction and Film. Ithaca: Cornell University Press.

Clark, Katerina 1981. The Soviet Novel: History as Ritual. Chicago: The University of Chicago Press.

Cox, Gary 1980. 'Fairy-Tale Plots and Contemporary Heroes in Early Russian Prose Fiction'. - Slavic Review $39,1,85-96$

Day, Jennifer J. 2005. 'Strange Spaces: Balabanov and the Petersburg Text'. - Slavic and East European Journal 49, 4, 612-624.

Fell, John T. 1977. 'Vladimir Propp in Hollywood'. - Film Quarterly 30, 19-203.

Hala, Jim 1992. 'Fatal Attraction and the Attraction of Fables: A Morphological Analysis'. - The Journal of Popular Culture 26, 3, 71-82.

Hashamova, Yana 2007. Pride and Panic: Russian Imagination of the West in Post-Soviet Film. Bristol: Intellect. 'Интервью' 2014 = 'Интервью Владимира Путина для ТАСС "Мы сильнее, потому что правы. Сила в правде". -

Politikus.ru, 24 November. http://politikus.ru/v-rossii/ 36430-intervyu-vladimira-putina-dlya-tass-mysilneepotomu-chto-pravy.-sila-v-pravde.html (12 September 2015).

Larsen, Susan 2003. 'National Identity, Cultural Authority, and the Post-Soviet Blockbuster: Nikita Mikhalkov and Aleksei Balabanov'. - Slavic Review 62, 2, 491-511. Lesinskis, Janis 2010. Applications of Vladimir Propp's Formalist Paradigm in the Production of Cinematic Narrative. MA thesis. RMIT University. Melbourne. http:// researchbank.rmit.edu.au/eserv/rmit:7520/Lesinskis. pdf (12 September 2015).

Липовецкий, Марк 2000. 'Всех люблю на свете я!' Искусство кино 11. http://kinoart.ru/archive/2000/11/ n11-article14 (12 September 2015).

Lipovetsky, Mark 2004. 'Post-Sots: Transformations of Socialist Realism in Popular Culture of the Recent Period: - The Slavic and East European Journal 48, 3 , 356-377.

Magnus, Leonard Arthur 1967. The Heroic Ballads of Russia. Port Washington: Kennikat Press.

Марголит, Евгений 1998. ‘Плач по пионеру, или Немецко е слово 'Яблокитай'. - Искусство кино 2. http://kinoart.ru/ archive/1998/02/n2-article9 (14 September 2015).

Meletinsky, E. M. 1975. 'The Low Hero of the Fairy Tale'. - Felix J. Oinas, Stephen Soudakoff (eds. and trans.), The Study of Russian Folklore. Slavistic Printings and Reprintings. Indiana University Textbook Series 4. Indiana University Folklore Institute Monograph Series 25. The Hague, Paris: Mouton: 235-276.

Mesropova, Olga 2008. 'Crime, Byt, and Fairy Tales: Daria Dontsova and Post-Soviet Ironical Detective
Fiction: - The Slavic and East European Journal 52, 1, 113-128.

Narváez, Peter; Laba, Martin 1986. 'Introduction: The Folklore-Popular Culture Continuum: - Peter Narváez, Martin Laba (eds.), Media Sense: The Folklore-Popular Culture Continuum. Bowling Green: Bowling Green State University Press, 1-8.

Obojski, Tim 1996. 'To Finder of 'National Idea' for Russia: 10 Million-Rouble Reward'. - Deutsche Presse-Agentur, 13 August.

‘Последний герой’ 2002. - Итоги, 1 October.

Propp, Vladimir 1968. Morphology of the Folktale. Trans. Laurence Scott. Austin: University of Texas Press.

Propp, Vladimir 1984. Theory and History of Folklore. Trans. Arianda Y. Martin, Richard P. Martin. Theory and History of Literature 5. Manchester: Manchester University Press.

Sherman, Sharon R.; Koven. Mikel J. 2007. 'Introduction: Popular Film as Vernacular Culture'. - Sharon R. Sherman, Mikel J. Koven (eds.), Folklore/Cinema: Popular Film as Vernacular Culture. Logan: Utah State University Press, 1-8.

Volodarsky, V. M. (ed.) 1979. The Tretyakov Gallery, Moscow: Russian Painting. Trans. B. Meyerovich. Leningrad: Aurora Art Publishers.

White, Frederick H. 2014. 'Interview with Lisa Rayel Jeffrey'. - KinoKultura: New Russian Cinema 45. http://www.kinokultura.com/2014/46i-white_jeffrey. shtml (2 March 2015).

Wigzell, Faith 2001. 'Folklore and Russian Literature'. Neil Cornwell (ed.), The Routledge Companion to Russian Literature. London, New York: Routledge, 36-48.

Wollen, Peter 1982. 'North by Northwest:

A Morphological Analysis'. - Film Form 1, 2, 19-34.

Zipes, Jack 1979. Breaking the Magic Spell: Radical Theories of Folk \& Fairy Tales. Austin: University of Texas Press.

Zvonkine, Eugénie 2007. 'The Structure of the Fairy Tale in Kira Muratova's The Sentimental Policeman: -

Studies in Russian and Soviet Cinema 1, 2, 131-145.

Österberg, Ira 2006. Гдемои крылья? Анаиз фильма Алексея Балабанова 'Брат'. MA Thesis. University of Helsinki. Helsinki. 